\title{
Removal Efficiency of $\mathrm{Cr}^{6+}$ by Indigenous Pichia sp. Isolated from Textile Factory Effluent
}

\author{
Pablo M. Fernández, ${ }^{1}$ María M. Martorell, ${ }^{1}$ Julia I. Fariña, ${ }^{1}$ and Lucia I. C. Figueroa ${ }^{1,2}$ \\ ${ }^{1}$ Planta Piloto de Procesos Industriales Microbiológicos PROIMI-CONICET, Avenida Belgrano y Caseros, \\ Tucumán T4001MVB, Argentina \\ ${ }^{2}$ Microbiología Superior, Facultad de Bioquímica, Química y Farmacia, Universidad Nacional de Tucumán UNT, \\ Tucumán 4000, Argentina \\ Correspondence should be addressed to Pablo M. Fernández, pmfernandez@argentina.com
}

Received 13 October 2011; Accepted 24 November 2011

Academic Editors: A. Akcil and M. C. Yebra-Biurrun

Copyright () 2012 Pablo M. Fernández et al. This is an open access article distributed under the Creative Commons Attribution License, which permits unrestricted use, distribution, and reproduction in any medium, provided the original work is properly cited.

\begin{abstract}
Resistance of the indigenous strains $P$. jadinii M9 and $P$. anomala M10, to high $\mathrm{Cr}^{6+}$ concentrations and their ability to reduce chromium in culture medium was studied. The isolates were able to tolerate chromium concentrations up to $104 \mu \mathrm{g} \mathrm{mL} \mathrm{m}^{-1}$. Growth and reduction of $\mathrm{Cr}^{6+}$ were dependent on incubation temperature, agitation, $\mathrm{Cr}^{6+}$ concentration, and $\mathrm{pH}$. Thus, in both studied strains the chromium removal was increased at $30^{\circ} \mathrm{C}$ with agitation. The optimum $\mathrm{pH}$ was different, with values of $\mathrm{pH} 3.0$ and $\mathrm{pH} 7.0$ in the case of $P$. anomala M10 and pH 7.0 using P. jadinii M9. Chromate reduction occurred both in intact cells (grown in culture medium) as well as in cell-free extracts. Chromate reductase activity could be related to cytosolic or membrane-associated proteins. The presence of a chromate reductase activity points out a possible role of an enzyme in $\mathrm{Cr}^{6+}$ reduction.
\end{abstract}

\section{Introduction}

Heavy metals found in wastewaters are harmful to the environment and their effects on biological systems are very severe. Chromium is one of the most widely used metals in industry, such as steel production, alloy preparation, wood preservation, leather tanning, metal corrosion inhibition, paints pigments, metal plating, tanning, and other industrial applications [1]. Chromium exists in several oxidation states from $\mathrm{Cr}^{2+}$ to $\mathrm{Cr}^{6+}$. In nature, trivalent and hexavalent forms are the dominant oxidation states. The toxicity of chromium is dependent on its oxidation state, $\mathrm{Cr}^{3+}$ is rather benign and easily adsorbed in soils and waters; whereas $\mathrm{Cr}^{6+}$, which is the toxic form, is not readily adsorbed and is soluble [2]. Thus, $\mathrm{Cr}^{6+}$, a carcinogenic element, is highly toxic to all forms of life but $\mathrm{Cr}^{3+}$, an essential micronutrient for many higher organisms, is relatively insoluble in water and 100 times less toxic than $\mathrm{Cr}^{6+}$ [3]. Chromium hexavalent toxicity is believed to be caused by the negatively charged chromate oxyanion, which can be easily transported into microbial cells. Once inside the cells, the oxyanion is believed to undergo immediate reduction reactions leading to the formation of various reactive intermediates, which are harmful to the cell organelles, proteins, and nucleic acids [4].

For that reason, it is important to develop an innovative, low cost, and ecofriendly method for the toxic heavy metal removal from the wastewater, instead of the conventional physical-chemical ones $[1,5]$. Several microorganisms have the exceptional ability to adapt to and colonize the noxious metal-polluted environments. These microorganisms have developed the capabilities to protect themselves from heavy metal toxicity by various mechanisms such as adsorption, uptake, methylation, oxidation, and reduction.

Yeasts are known for playing an important role in the removal of toxic heavy metals [4, 6, 7]. Furthermore, the occurrence of indigenous $\mathrm{Cr}^{6+}$ reducing eukaryotic microorganisms, including those not related with $\mathrm{Cr}^{6+}$ contamination, has emerged as an important nonconventional yeastsbased bioremediation method with significant biological relevance and biotechnological applications.

Microbial $\mathrm{Cr}^{6+}$ tolerance and $\mathrm{Cr}^{6+}$ reduction are independent events. However, for the $\mathrm{Cr}^{6+}$-reduction cells must 
tolerate $\mathrm{Cr}^{6+}$, otherwise the cell growth is inhibited. Some authors argue that the microbial reduction of $\mathrm{Cr}^{6+}$ can be considered as an additional mechanism of resistance to chromate, which is usually not encoded in plasmids [8]. The enzymatic biospeciation of $\mathrm{Cr}^{6+}$ to $\mathrm{Cr}^{3+}$ with eukaryotic microorganisms was reported in Candida maltose [9], C. utilis [10], fungi Hypocrea tawa [11], and Aspergillus [12]. But it was not possible to continue with the purification and characterization of the protein involved, therefore available information is scarce. In this context, the study of specific chromate reductases is meaningful to understand the cellular mechanisms in future bioremediation processes.

The present study deals with the ability of $P$. jadinii M9 and $P$. anomala M10 to grow and remove chromium in batch cultures and using cell-free extracts. The effects of different factors on $\mathrm{Cr}^{6+}$ removal, including $\mathrm{pH}$, temperature, agitation, and initial $\mathrm{Cr}^{6+}$ concentration were also considered and optimum removal parameters were established.

\section{Materials and Methods}

2.1. Yeast Strains and Culture Conditions. Chromate-resistant yeasts Pichia jadinii M9 and Pichia anomala M10, previously isolated from textile factory effluents (Tucumán, Argentina) were used [13]. For the inocula, the yeast strains were grown in $500 \mathrm{~mL}$-Erlenmeyer flasks containing $100 \mathrm{~mL}$ of Czapek malta medium using methodology described by Fernández et al. [13].

Chromium removal experiments were performed using YNB' medium amended with $\mathrm{Cr}^{6+}$ and inoculated with a constant biomass. YNB' medium was chosen based on previous assays that confirmed lower interferences of this medium during Cr-bioremediation and $\mathrm{Cr}^{6+}$-quantification by 1,5-diphenylcarbazide (DPC) [14]. YNB' composition (in $g$ $\mathrm{L}^{-1}$ ) was $10 \times$ yeast nitrogen base (YNB w/o amino acids and ammonium sulfate; Difco), $10 \%\left(\mathrm{v} \mathrm{v}^{-1}\right)$; sucrose, 50; ammonium sulfate, $0.6 ; \mathrm{pH}$ 5.0. All the experimental sets were performed on a rotary shaker $\left(250 \mathrm{rev} \mathrm{min}^{-1}\right)$ at $25^{\circ} \mathrm{C}$ in $250 \mathrm{~mL}$ Erlenmeyer flasks containing $50 \mathrm{~mL}$ of culture medium, unless otherwise stated.

The $\mathrm{Cr}^{6+}$ (as $\mathrm{K}_{2} \mathrm{Cr}_{2} \mathrm{O}_{7}$ or $\mathrm{K}_{2} \mathrm{CrO}_{4}$ ) stock solution $\left(5,200 \mu \mathrm{g} \mathrm{mL}^{-1}\right)$ was prepared in bidistilled water and filtersterilized $(0.2 \mu \mathrm{m}$-cellulose acetate membrane filter; Sartorius).

2.2. Effect of $\mathrm{Cr}^{6+}$ on Yeasts Growth. Chromate resistance test and growth curves were determined in YNB' medium supplemented with the desired $\mathrm{Cr}^{6+}$ concentration and without chromium (control). Growth was monitored at specific time intervals by biomass dry weight (BDW). Samples from culture were spun down at $10,000 \times \mathrm{g}$ for $10 \mathrm{~min}$. The distilled water suspended pellet was filtered through a $0.45 \mu \mathrm{m}$ cellulose acetate membrane filter (Sartorius) and dried at $85^{\circ} \mathrm{C}$ until constant weight to determine BDW in $\mathrm{g} \mathrm{L}^{-1}$ [13]. For determination of $\mathrm{Cr}^{6+}$ concentration, a miniaturized protocol was developed as follows: to $50 \mu \mathrm{L}$ of sample supernatant, $50 \mu \mathrm{L}$ of $0.2 \mathrm{~N} \mathrm{H}_{2} \mathrm{SO}_{4}$ were added and the volume was made up to $2 \mathrm{~mL}$ with distilled water.
After mixing with $40 \mu \mathrm{L}$ of $5 \mathrm{mg} \mathrm{DPC} \mathrm{mL}-1$ acetone, the mixture was allowed to stand for $10 \mathrm{~min}$ and spectrophotometric determinations were performed at $540 \mathrm{~nm}$ (Beckman DU640) against a reagent blank. $\mathrm{Cr}^{6+}$ concentrations were quantified by the use of an external $\mathrm{K}_{2} \mathrm{Cr}_{2} \mathrm{O}_{7}$ standard with a 7-point calibration curve [14].

2.3. Factors Affecting $\mathrm{Cr}^{6+}$ Removal. To characterize the $\mathrm{Cr}^{6+}$ reduction efficiency by strains $\mathrm{M} 9$ and $\mathrm{M} 10$, the effects of temperature $\left(10,20,25,30^{\circ} \mathrm{C}\right)$, initial $\mathrm{pH}(3.0,5.0,7.0,9.0)$, agitation $\left(0,150,250 \mathrm{rev} \mathrm{min}^{-1}\right)$, and initial $\mathrm{Cr}^{6+}$ concentration $\left(26-104 \mu \mathrm{g} \mathrm{mL}^{-1}\right)$ were investigated. $\mathrm{Cr}^{6+}$ reduction was studied in aerobic batch cultures. The following set of standard conditions was chosen as the starting point: $52 \mu \mathrm{g} \mathrm{mL}^{-1}$ of initial $\mathrm{Cr}^{6+}$ concentration, $\mathrm{pH} 5.0,25^{\circ} \mathrm{C}$ and $250 \mathrm{rev} \mathrm{min}^{-1}$. Samples were withdrawn at defined times and analyzed for disappearance of $\mathrm{Cr}^{6+}$ as described above. In order to monitor any abiotic $\mathrm{Cr}^{6+}$ reduction, cell-free control experiments were carried out for each assayed condition.

2.4. Preparation of Cell-Free Extract and Enzymatic Determinations. To prepare the crude cell-free extract, the yeast cultures were grown in $200 \mathrm{~mL}$ YNB' medium for $48 \mathrm{~h}$ at $25^{\circ} \mathrm{C}$ with $52 \mu \mathrm{g} \mathrm{mL}^{-1} \mathrm{Cr}^{6+}$ and without chromium (control). Cells were harvested by centrifugation at $10,000 \times \mathrm{g}$ for $10 \mathrm{~min}$. Pellets were washed twice with $50 \mathrm{mM}$ phosphatecitrate buffer $(\mathrm{pH} 5.0)$ and suspended in the same buffer with protease inhibitor cocktail (SET1; Calbiochem) plus a volume of sterilized glass beads. Cells were disrupted by sonication for $5 \mathrm{~min}$ in cold environment conidtions (5 cycles: 59 seg on, 30 seg off; Sonics Vibra Cell VCX 130). The homogenate was centrifuged at $10,000 \times \mathrm{g}$ for $10 \mathrm{~min}$ at $4^{\circ} \mathrm{C}$ to remove cell walls and unbroken cells. The supernatant filtered through a $0.2 \mu \mathrm{m}$ cellulose acetate membrane filter was used as a crude extract and called cell-free extract (CFE). Decrease of chromate concentration by CFE was assayed after $30 \mathrm{~min}$ at $30^{\circ} \mathrm{C}$ using $50 \mu \mathrm{L}$ of sample preparation in $0.25 \mathrm{~mL}$ reaction mixtures containing (to a final concentration): $50 \mathrm{mM}$ phosphate-citrate buffer ( $\mathrm{pH} 5.0$ ), $26 \mu \mathrm{g}$ $\mathrm{mL}^{-1} \mathrm{~K}_{2} \mathrm{CrO}_{4}, 1 \mathrm{mM} \mathrm{NADH}$; these concentrations were saturating and noninhibitory under these conditions. The reaction was started by addition of chromate to the reaction mixture. Hexavalent chromium was spectrophotometrically quantified, as previously described. Protein was determined using Bicinchoninic Acid Kit (BCA, Sigma), with BSA as standard.

\section{Results and Discussion}

3.1. Effect of Initial $\mathrm{Cr}^{6+}$ Concentration on Cells Growth. $\mathrm{Cr}^{6+}$ resistance of $P$. jadinii M9 and $P$. anomala M10 was evaluated by growth response of the strains under different concentrations of $\mathrm{Cr}^{6+}$. Growth curves of yeast isolates with or without $\mathrm{Cr}^{6+}$ were plotted (Figures 1(a), 1(b)). The cells grew well in the medium with a range of initial $\mathrm{Cr}^{6+}$ concentration of $26-104 \mu \mathrm{g} \mathrm{mL}^{-1}$. However, the growth curves of $P$. jadinii M9 and P. anomala M10 in the medium containing $\mathrm{Cr}^{6+}$ did not follow the same growth pattern as the control, indicating 


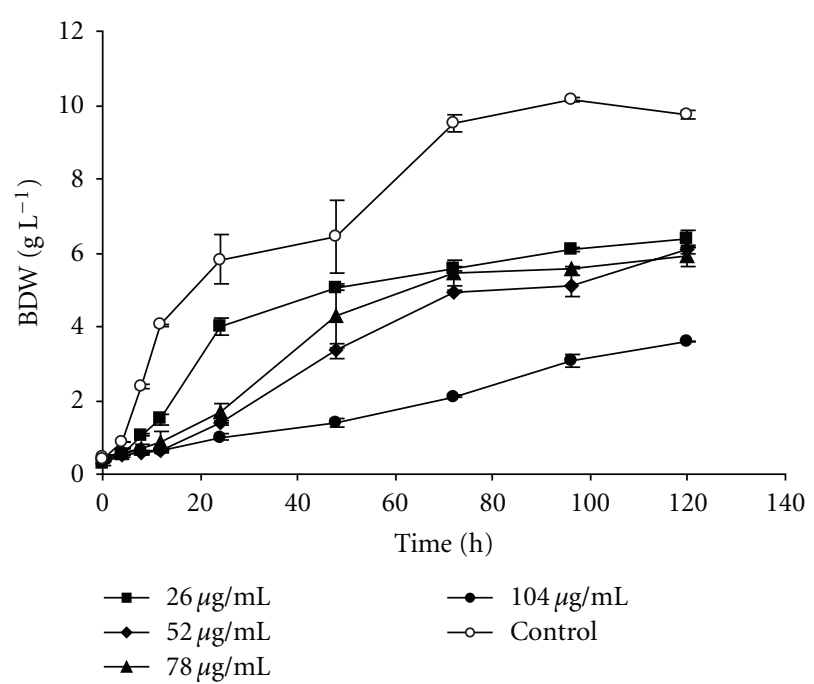

(a)

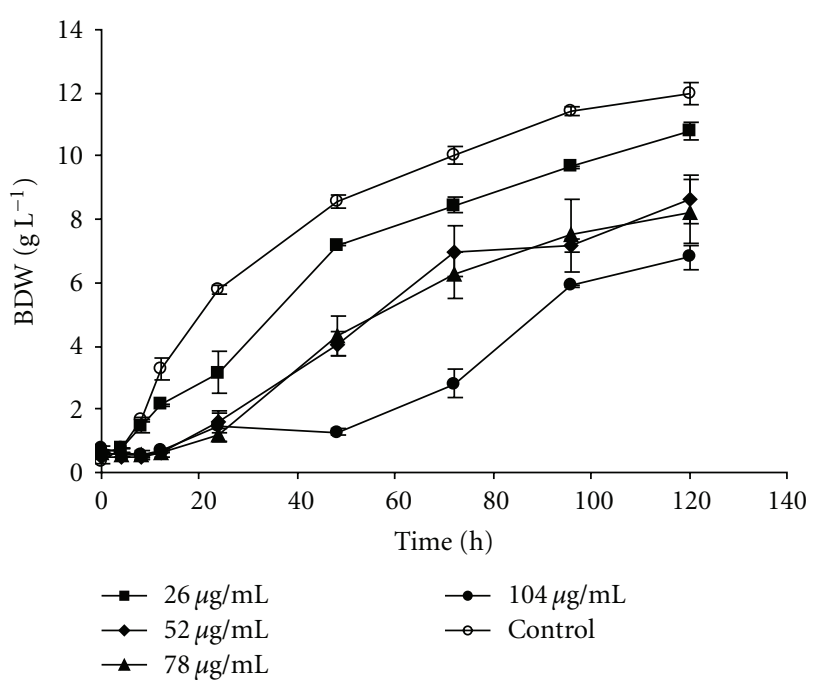

(b)

FIGURE 1: Growth curves of $P$. jadinii M9 (a) and P. anomala M10 (b) at varying $\mathrm{Cr}^{6+}$ concentrations as $\mathrm{K}_{2} \mathrm{Cr}_{2} \mathrm{O}_{7}$.

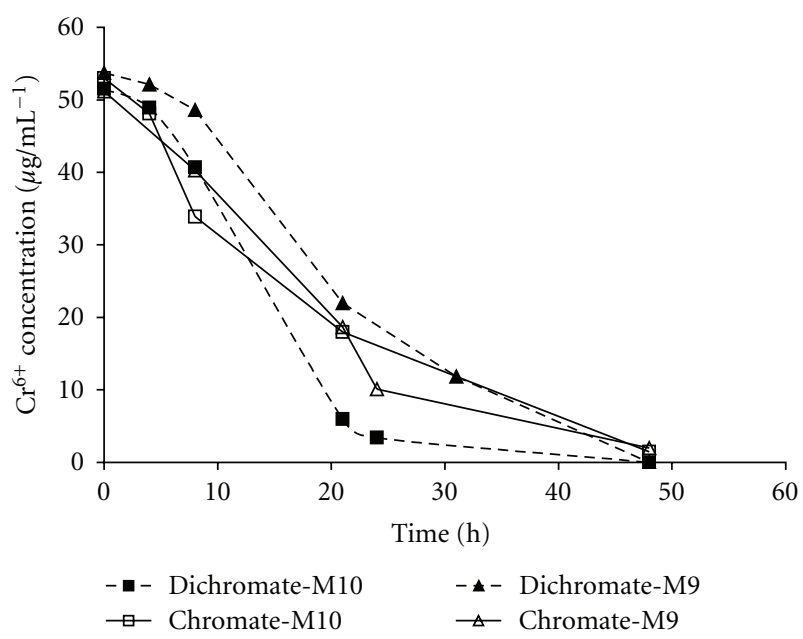

Figure 2: $\mathrm{Cr}^{6+}$-removal yield by $P$. jadinii $\mathrm{M} 9$ and $P$. anomala M10 exposed to different forms of $\mathrm{Cr}^{6+}$ (chromate: $\mathrm{CrO}_{4}{ }^{-2}$ and dichromate: $\mathrm{Cr}_{2} \mathrm{O}_{7}{ }^{-2}$ ) at $52 \mu \mathrm{g} \mathrm{mL} \mathrm{m}^{-1}$ initial $\mathrm{Cr}^{6+}$ concentration during $48 \mathrm{~h}$.

a possible toxic effect of $\mathrm{Cr}^{6+}$ on the cells. It was obvious that the growth of cells was heavily influenced by $\mathrm{Cr}^{6+}$ at a concentration of $104 \mu \mathrm{g} \mathrm{mL}^{-1}$ (biomass concentration drop a $63 \%$ and $56 \%$ for $P$. jadinii M9 and P. anomala M10, resp.), but it did not suppressed the cells growth. The experiments conducted with $\mathrm{Cr}^{6+}$ concentrations of 26,52 , $78 \mu \mathrm{g} \mathrm{mL} \mathrm{m}^{-1}$ had only slight effects on the growth (Figures 1(a), 1(b)). The P. jadinii M9 and P. anomala M10 strains completely reduced all $\mathrm{Cr}^{6+}$ concentrations tested; thus, overall efficiency of $\mathrm{Cr}^{6+}$ reduction (100\%) was not affected by initial $\mathrm{Cr}^{6+}$ concentration. The highest concentration of $\mathrm{Cr}^{6+}\left(104 \mu \mathrm{g} \mathrm{mL}^{-1}\right)$ that allowed growth and was completely reduced by $P$. jadinii M9 and $P$. anomala M10 was much higher than concentrations commonly found to be reduced by bacteria [15], yeasts [9], and filamentous fungi [16]. However, it is important to consider that the microbial chromate-resistance and chromate-reduction parameters are correlated with medium composition and cell density [13]. The real toxicity of $\mathrm{Cr}^{6+}$ could be masked or underestimated due to complexation of $\mathrm{Cr}^{6+}$ with organic components. The minimal medium used in our study eliminated/minimized the possible complexation of $\mathrm{Cr}^{6+}$ with media components and allowed the assessment of the toxicity of $\mathrm{Cr}^{6+}$ more accurately.

In both strains, it was observed that, although residual $\mathrm{Cr}^{6+}$ concentration decreased as incubation progressed, total chromium in solution remained virtually constant (data not showed, Fernández et al., unpublished) and chromium did not accumulate in the cell, which indicates that $P$. jadinii M9 and $P$. anomala M10 were able to reduce chromium to forms of lower valency. Taking into consideration that the more stable forms of chromium are the trivalent and hexavalent ones [17], it seems most likely that the M9 and M10 strains were capable of transforming the highly toxic and soluble hexavalent chromium to the less toxic and mobile trivalent form.

Hexavalent chromium reduction potential of $P$. jadinii M9 and $P$. anomala M10 was assessed with two kinds of $\mathrm{Cr}^{6+}$ salts, $\mathrm{K}_{2} \mathrm{CrO}_{4}$ (chromate), and $\mathrm{K}_{2} \mathrm{Cr}_{2} \mathrm{O}_{7}$ (dichromate). $\mathrm{Cr}^{6+}$ (at initial concentration of $52 \mu \mathrm{g} \mathrm{mL}^{-1}$ ) was reduced up to $100 \%$ by both strains within $48 \mathrm{~h}$ (Figure 2). Importantly, $\mathrm{Cr}^{6+}$ occurs in aquatic environment either as $\mathrm{CrO}_{4}{ }^{2-}$ or $\mathrm{Cr}_{2} \mathrm{O}_{7}{ }^{2-}[18]$ and the strains used in this study were able to reduce both forms of hexavalent chromium.

3.2. Factors Affecting $\mathrm{Cr}^{6+}$ Reduction. The effect of initial $\mathrm{Cr}^{6+}$ concentration on $\mathrm{Cr}^{6+}$ reduction was investigated over a range of $26-104 \mu \mathrm{g} \mathrm{mL}^{-1}$ under aerobic conditions. As shown in Table $1, \mathrm{Cr}^{6+}$ reduction occurred even at the highest concentration of $104 \mu \mathrm{g} \mathrm{mL}^{-1}$, and the time taken 
TABle 1: The effect of factors on $\mathrm{Cr}^{6+}$ removal, including $\mathrm{pH}$, temperature, agitation, and initial $\mathrm{Cr}^{6+}$ concentration.

\begin{tabular}{|c|c|c|}
\hline \multirow[t]{2}{*}{ Parameters } & \multicolumn{2}{|c|}{ Time for complete $\mathrm{Cr}^{6+}$ removal $(\mathrm{h})$} \\
\hline & Strains & \\
\hline $\begin{array}{l}\text { Initial } \mathrm{Cr}^{6+} \text { concentration } \\
\left(\mu \mathrm{g} \mathrm{mL}^{-1}\right)\end{array}$ & P. jadinii M9 & P. anomala M10 \\
\hline 26 & 12 & 8 \\
\hline 52 & 48 & 24 \\
\hline 78 & 48 & 48 \\
\hline 104 & 96 & 72 \\
\hline \multicolumn{3}{|l|}{ Temperature $\left({ }^{\circ} \mathrm{C}\right)$} \\
\hline 10 & +120 & 72 \\
\hline 20 & 48 & 24 \\
\hline 25 & 48 & 24 \\
\hline 30 & 24 & 8 \\
\hline \multicolumn{3}{|l|}{ Agitation $\left(\right.$ rev $\left.\min ^{-1}\right)$} \\
\hline 0 & 48 & 72 \\
\hline 150 & 48 & 24 \\
\hline 250 & 48 & 24 \\
\hline \multicolumn{3}{|l|}{$\mathrm{pH}$} \\
\hline 3 & +120 & 8 \\
\hline 5 & 48 & 24 \\
\hline 7 & 12 & 12 \\
\hline 9 & +120 & 48 \\
\hline
\end{tabular}

Reference +120 : complete $\mathrm{Cr}^{6+}$ removal was not achieved after $120 \mathrm{~h}$ culture.

for total reduction of $\mathrm{Cr}^{6+}$ increased with increasing concentration of $\mathrm{Cr}^{6+}$. Complete $\mathrm{Cr}^{6+}$ reduction was observed at 96 and $72 \mathrm{~h}$, for $P$. jadinii M9 and P. anomala M10, respectively. Megharaj et al. [19] also observed that the time required for total $\mathrm{Cr}^{6+}$ reduction increased with increasing initial $\mathrm{Cr}^{6+}$ concentration. The Pseudomonad strain CRB5 showed complete reduction of $20 \mu \mathrm{g} \mathrm{mL}^{-1}$ of chromate after 120 h [18], whilst B. sphaericus AND303 failed to completely reduce $10 \mu \mathrm{g} \mathrm{mL}^{-1}$ of $\mathrm{Cr}^{6+}$ [20].

Initial culture medium $\mathrm{pH}$ was considered as a relevant factor for growth and $\mathrm{Cr}^{6+}$ removal by strains $\mathrm{M} 9$ and $\mathrm{M} 10$. The time required for complete removal of $\mathrm{Cr}^{6+}$ in every experimental set is listed in Table 1 . The optimum $\mathrm{pH}$ for the strain $P$. jadinii $\mathrm{M} 9$ was $\mathrm{pH}$ 7.0. In the case of $P$. anomala $\mathrm{M} 10$, the optimum $\mathrm{pH}$ for $\mathrm{Cr}^{6+}$ reduction was $\mathrm{pH}$ 3.0. Nonetheless, strain M10 was also capable of reducing $\mathrm{Cr}^{6+}$ in the range of 3.0-9.0 with an appreciable efficiency at neutral $\mathrm{pH}$. Some authors have reported that reduction of chromium in various fungal strains, such as Rhizopus nigricans [21], $R$. arrhizus [22], and Mucor hiemalis [23] occurred at $\mathrm{pH} 2.0-$ 3.0. It is known that a drop in $\mathrm{pH}$ causes the protonation of the adsorbent surface, inducing a strong attraction of negatively charged $\mathrm{Cr}^{6+}$-ions. Accordingly, biosorption increased with increasing acidity of the solution. The opposite would occur with increasing $\mathrm{pH}$, inducing changes in the adsorbent surface, thereby preventing the $\mathrm{Cr}^{6+}$-ion biosorption. On the other side, Farrell and Ranallo [24] noted that in enzymatic $\mathrm{Cr}^{6+}$ reduction, changes in $\mathrm{pH}$ affect the degree of enzyme ionization, with protein conformation and enzyme activity modifications. This would explain why the acidity is not absolutely critical for a better $\mathrm{Cr}^{6+}$ removal. Related, $P$. anomala M10 showed two optimum $\mathrm{pH}$ values. The lowest ( $\mathrm{pH}$ 3.0) could be related to stimulation of the biosorption phenomena, while $\mathrm{pH} 7.0$ could be linked to improved enzymatic $\mathrm{Cr}^{6+}$ reduction. No measurable changes in $\mathrm{Cr}^{6+}$ concentrations were detected after $120 \mathrm{~h}$ of incubation in cell-free controls at the different $\mathrm{pH}$ values assayed. These results suggest that $\mathrm{Cr}^{6+}$ removal by medium components was not significant in these experiments and also indicate that $\mathrm{Cr}^{6+}$ reduction observed in the $\mathrm{Cr}^{6+}$ removal experiments conducted with cells was not due to the $\mathrm{pH}$ changes that occurred as result of metabolic activity of the growing cells.

Temperature was also an important factor on microbial $\mathrm{Cr}^{6+}$ removal. Chromate removal, by strains $P$. jadinii M9 and $P$. anomala M10 was evaluated under four different temperatures: $10,20,25$, and $30^{\circ} \mathrm{C}$ for $120 \mathrm{~h}$. These strains reduced $\mathrm{Cr}^{6+}$ in the culture medium more rapidly with an increment in temperature, with an optimum value of $30^{\circ} \mathrm{C}$, as shown in Table 1. Generally, an increase in temperature increases the $\mathrm{Cr}^{6+}$-removal rate and reduces the contact time required for metal-removal, which is due to a direct increase in the rate of redox reaction [25]. Similarly, the optimum temperature for $\mathrm{Cr}^{6+}$ reduction by Bacillus sp. [26] and Pseudomonad strain CRB5 was $30^{\circ} \mathrm{C}$ [27].

The results of shaken versus stationary cultures are presented in Table 1. Generally, $\mathrm{Cr}^{6+}$ removal was enhanced by shaking the cultures, but strains $P$. jadinii M9 and $P$. anomala M10 could achieve a complete removal (100\%) of the metal, both at stationary and shaken states. The aeration and the cell/metal contact are directly related to the removal of it. However, the alternative to remediate $\mathrm{Cr}^{6+}$ without agitation is particularly important for in situ bioremediation applications and may represent a valuable advantage from the economic point of view.

3.3. Chromate Reduction by Cell-Free Extract (CFE). Yeast cells recovered from cultures grown in the presence of $52 \mu \mathrm{g}$ $\mathrm{mL}^{-1}$ of $\mathrm{Cr}^{6+}$ and without $\mathrm{Cr}^{6+}$ (control) were tested for chromate reductase activity. The concentration of protein obtained in CFE from cultures with $\mathrm{Cr}^{6+}$ was two times higher than the control ones (Figure 3(a)). The chromate reductase specific activity in the CFE of $P$. jadinii M9 was higher in cultures with $\mathrm{Cr}^{6+}$, which could be interpreted as an induction by the metal present in the culture medium. In the case of $P$. anomala M10, there were no significant differences in chromate reductase specific activity between the different CFEs (Figure 3(b)). Das and Chandra [28] studied a strain of Streptomyces sp. M3 and noticed an increase in the chromate reductase activity when working in cultures with $\mathrm{Cr}^{6+}$. These same authors found that enzymeexpression was constitutive. Chromate reductase enzymes with constitutive expression were also discovered in Bacillus species $[29,30]$. In the case of constitutive expression, it could be possible that the activity was not specific for this metal and, therefore, normally expressed in cells. It could also take place by induction of some other components 


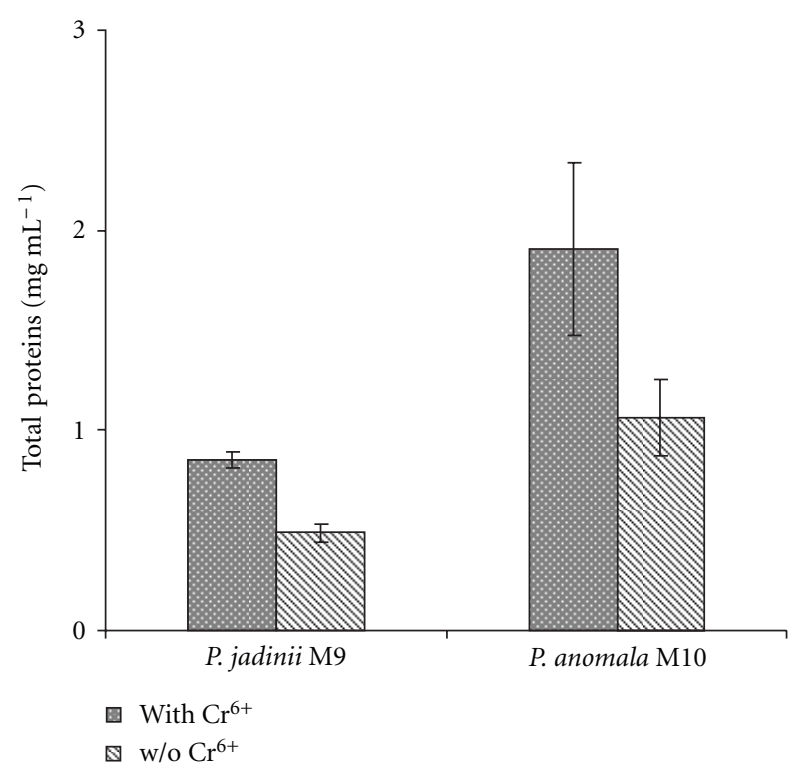

(a)

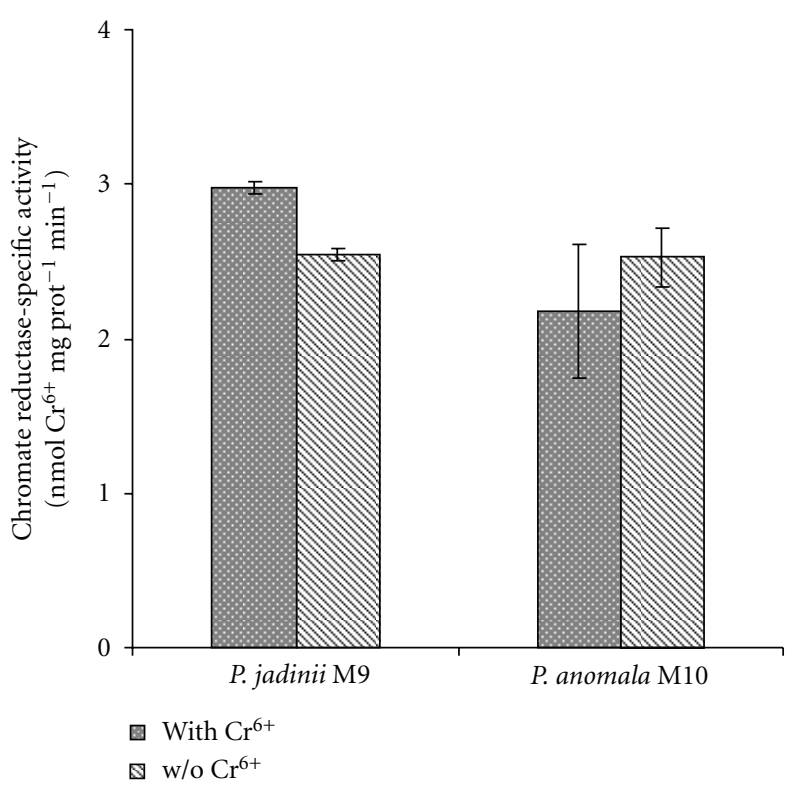

(b)

FIGURE 3: Total proteins (a) and chromate reductase-specific activity (b) in cell-free extract of P. jadinii M9 and P. anomala M10 grown with or without $\mathrm{Cr}^{6+}$. The reaction was started by addition of chromate, and the mixture was incubated at $30^{\circ} \mathrm{C}$ for $30 \mathrm{~min}$.

of the culture medium with or without $\mathrm{Cr}^{6+}$. Kwak et al. [31] reported the presence of chromate reductase activity in $V$. harveyi, which also had nitroreductase activity. In $P$. denitrificans, the iron reductase (Ferb) also showed chromate reductase activity [32].

It is important to point out that the specific chromate reductase activity in the cells from cultures with $\mathrm{Cr}^{6+}$ could be masked by an increase in the concentration of other proteins not related with the metal reduction. That could be happening in the case of P. anomala M10 (Figure 3(b)). This protein could be part of a protective mechanism in response to the stress suffered in the presence of $\mathrm{Cr}^{6+}$. However, to date most of the proteins that undergo changes in presence of $\mathrm{Cr}^{6+}$ have not yet been identified, and therefore, its particular function could not be determined.

These data indicate that the chromate reductase activity present in CFE of $P$. jadinii M9 and $P$. anomala M10 could be related with cytosolic or associated membrane proteins, which in this respect resembles the activity found in chromate-resistant bacteria [30], and Candida maltosa RR1 [9].

\section{Conclusions}

Environmental isolates $P$. jadinii M9 and P. anomala M10 can be exploited for bioremediation of hexavalent chromium, since they are chromate-resistant yeasts and possess the capability to reduce the toxic hexavalent form to its nontoxic trivalent form. The results obtained may provide useful information for the removal of chromate under a wide range of environmental conditions. Systematic studies are needed to determine the real nature of activities so far called as chromate reductases. A future communication will deal with the chromate reductase activities characterization. This information will greatly facilitate the use of the involved proteins to enhance the chromate remediation potential of P. jadinii M9 and P. anomala M10.

\section{Acknowledgments}

Financial support was provided by Agencia Nacional de Promoción Científica y Tecnológica-FONCYT (PICT-2007568 Préstamo BID) and Consejo de Investigaciones de la Universidad Nacional de Tucumán, CIUNT (D-415). Pablo M. Fernández and María M. Martorell equally contributed to this work.

\section{References}

[1] J. K. Tseng and A. R. Bielefeldt, "Low-temperature chromium(VI) biotransformation in soil with varying electron acceptors," Journal of Environmental Quality, vol. 31, no. 6, pp. 1831-1841, 2002.

[2] J. Kotaś and Z. Stasicka, "Chromium occurrence in the environment and methods of its speciation," Environmental Pollution, vol. 107, no. 3, pp. 263-283, 2000.

[3] L. Morales-Barrera and E. Cristiani-Urbina, "Removal of hexavalent chromium by Trichoderma viride in an airlift bioreactor," Enzyme and Microbial Technology, vol. 40, no. 1, pp. 107113, 2006.

[4] H. Ksheminska, D. Fedorovych, L. Babyak, D. Yanovych, P. Kaszycki, and H. Koloczek, "Chromium(III) and (VI) tolerance and bioaccumulation in yeast: a survey of cellular chromium content in selected strains of representative genera," Process Biochemistry, vol. 40, no. 5, pp. 1565-1572, 2005. 
[5] J. Juvera-Espinosa, L. Morales-Barrera, and E. CristianiUrbina, "Isolation and characterization of a yeast strain capable of removing $\mathrm{Cr}(\mathrm{VI})$," Enzyme and Microbial Technology, vol. 40, no. 1, pp. 114-121, 2006.

[6] F. M. Guillén-Jiménez, L. Morales-Barrera, L. MoralesJiménez, C. H. Hernández-Rodríguez, and E. Cristiani-Urbina, "Modulation of tolerance to $\mathrm{Cr}(\mathrm{VI})$ and $\mathrm{Cr}(\mathrm{VI})$ reduction by sulphate ion a Candida yeast strain isolated from tannery wastewater," Journal of Industrial Microbiology and Biotechnology, vol. 35, pp. 1277-1287, 2008.

[7] L. B. Villegas, P. M. Fernández, M. J. Amoroso, and L. I. C. De Figueroa, "Chromate removal by yeasts isolated from sediments of a tanning factory and a mine site in Argentina," BioMetals, vol. 21, no. 5, pp. 591-600, 2008.

[8] C. Cervantes, J. Campos-García, S. Devars et al., "Interactions of chromium with microorganisms and plants," FEMS Microbiology Reviews, vol. 25, no. 3, pp. 335-347, 2001.

[9] R. Ramírez-Ramírez, C. Calvo-Méndez, M. Ávila-Rodríguez et al., " $\mathrm{Cr}(\mathrm{VI})$ reduction in a chromate-resistant strain of Candida maltosa isolated from the leather industry," Antonie van Leeuwenhoek, vol. 85, no. 1, pp. 63-68, 2004.

[10] O. Muter, A. Patmalnieks, and A. Rapoport, "Interrelations of the yeast Candida utilis and $\mathrm{Cr}(\mathrm{VI})$ : metal reduction and its distribution in the cell and medium," Process Biochemistry, vol. 36, no. 10, pp. 963-970, 2001.

[11] L. Morales-Barrera, F. D. M. Guillén-Jiménez, A. OrtizMoreno et al., "Isolation, identification and characterization of a Hypocrea tawa strain with high $\mathrm{Cr}(\mathrm{VI})$ reduction potential," Biochemical Engineering Journal, vol. 40, no. 2, pp. 284-292, 2008.

[12] S. Srivastava and I. S. Thakur, "Isolation and process parameter optimization of Aspergillus sp. for removal of chromium from tannery effluent," Bioresource Technology, vol. 97, no. 10, pp. 1167-1173, 2006.

[13] P. M. Fernández, J. I. Fariña, and L. I. C. Figueroa, "The significance of inoculum standardization and cell density on the $\mathrm{Cr}(\mathrm{VI})$ removal by environmental yeast isolates," Water, Air, and Soil Pollution, vol. 212, no. 1-4, pp. 275-279, 2010.

[14] P. M. Fernández, L. I. C. Figueroa, and J. I. Fariña, "Critical influence of culture medium and $\mathrm{Cr}$ (III) quantification protocols on the interpretation of $\mathrm{Cr}(\mathrm{VI})$ bioremediation by environmental fungal isolates," Water, Air, and Soil Pollution, vol. 206, no. 1-4, pp. 283-293, 2010.

[15] K. H. Cheung and J. D. Gu, "Reduction of chromate $\left(\mathrm{CrO}_{4}{ }^{2-}\right)$ by an enrichment consortium and an isolate of marine sulfatereducing bacteria," Chemosphere, vol. 52, no. 9, pp. 1523-1529, 2003.

[16] F. J. Acevedo-Aguilar, A. E. Espino-Saldaña, I. L. LeonRodriguez et al., "Hexavalent chromium removal in vitro and from industrial wastes, using chromate-resistant strains of filamentous fungi indigenous to contaminated wastes," Canadian Journal of Microbiology, vol. 52, no. 9, pp. 809-815, 2006.

[17] M. QuiIntana, G. Curutchet, and E. Donati, "Factors affecting chromium(VI) reduction by Thiobacillus ferrooxidans," Biochemical Engineering Journal, vol. 9, no. 1, pp. 11-15, 2001.

[18] J. Mclean and T. J. Beveridge, "Chromate reduction by a Pseudomonad isolated from a site contaminated with chromated copper arsenate," Applied and Environmental Microbiology, vol. 67, no. 3, pp. 1076-1084, 2001.

[19] M. Megharaj, S. Avudainayagam, and R. Naidu, "Toxicity of hexavalent chromium and its reduction by bacteria isolated from soil contaminated with tannery waste," Current Microbiology, vol. 47, no. 1, pp. 51-54, 2003.

[20] A. Pal and A. K. Paul, "Aerobic chromate reduction by chromium-resistant bacteria isolated from serpentine soil," Microbiological Research, vol. 159, no. 4, pp. 347-354, 2004.

[21] S. Bai R and T. E. Abraham, "Biosorption of Cr (VI) from aqueous solution by Rhizopus nigricans," Bioresource Technology, vol. 79, no. 1, pp. 73-81, 2001.

[22] Y. Sağ and Y. Aktay, "Kinetic studies on sorption of $\mathrm{Cr}(\mathrm{VI})$ and $\mathrm{Cu}(\mathrm{II})$ ions by chitin, chitosan and Rhizopus arrhizus," Biochemical Engineering Journal, vol. 12, no. 2, pp. 143-153, 2002.

[23] N. Tewari, P. Vasudevan, and B. K. Guha, "Study on biosorption of $\mathrm{Cr}(\mathrm{VI})$ by Mucor hiemalis," Biochemical Engineering Journal, vol. 23, no. 2, pp. 185-192, 2005.

[24] S. O. Farrell and R. T. Ranallo, Experiments in Biochemistry. A Hands-On Approach, Saunders College Publishing, Orlando, Fla, USA, 2000.

[25] P. R. Wittbrodt and C. D. Palmer, "Effect of temperature, ionic strength, background electrolytes, and $\mathrm{Fe}(\mathrm{III})$ on the reduction of hexavalent chromium by soil humic substances," Environmental Science and Technology, vol. 30, no. 8, pp. 24702477, 1996.

[26] Y. T. Wang and C. Xiao, "Factors affecting hexavalent chromium reduction in pure cultures of bacteria," Water Research, vol. 29, no. 11, pp. 2467-2474, 1995.

[27] J. S. McLean, T. J. Beveridge, and D. Phipps, "Isolation and characterization of a chromium-reducing bacterium from a chromated copper arsenate-contaminated site," Environmental Microbiology, vol. 2, no. 6, pp. 611-619, 2000.

[28] S. Das and A. L. Chandra, "Chromate reduction in streptomyces," Experientia, vol. 46, no. 7, pp. 731-733, 1990.

[29] A. Pal, S. Dutta, P. K. Mukherjee, and A. K. Paul, "Occurrence of heavy metal-resistance in microflora from serpentine soil of Andaman," Journal of Basic Microbiology, vol. 45, no. 3, pp. 207-218, 2005.

[30] C. Desai, K. Jain, and D. Madamwar, "Evaluation of in vitro $\mathrm{Cr}(\mathrm{VI})$ reduction potential in cytosolic extracts of three indigenous Bacillus sp. isolated from $\mathrm{Cr}(\mathrm{VI})$ polluted industrial landfill," Bioresource Technology, vol. 99, no. 14, pp. 6059-6069, 2008.

[31] Y. H. Kwak, D. S. Lee, and H. B. Kim, "Vibrio harveyi nitroreductase is also a chromate reductase," Applied and Environmental Microbiology, vol. 69, no. 8, pp. 4390-4395, 2003.

[32] J. Mazoch, R. Tesař́k, V. Sedláček, I. Kučera, and J. Turánek, "Isolation and biochemical characterization of two soluble iron(III) reductases from Paracoccus denitrificans," European Journal of Biochemistry, vol. 271, no. 3, pp. 553-562, 2004. 

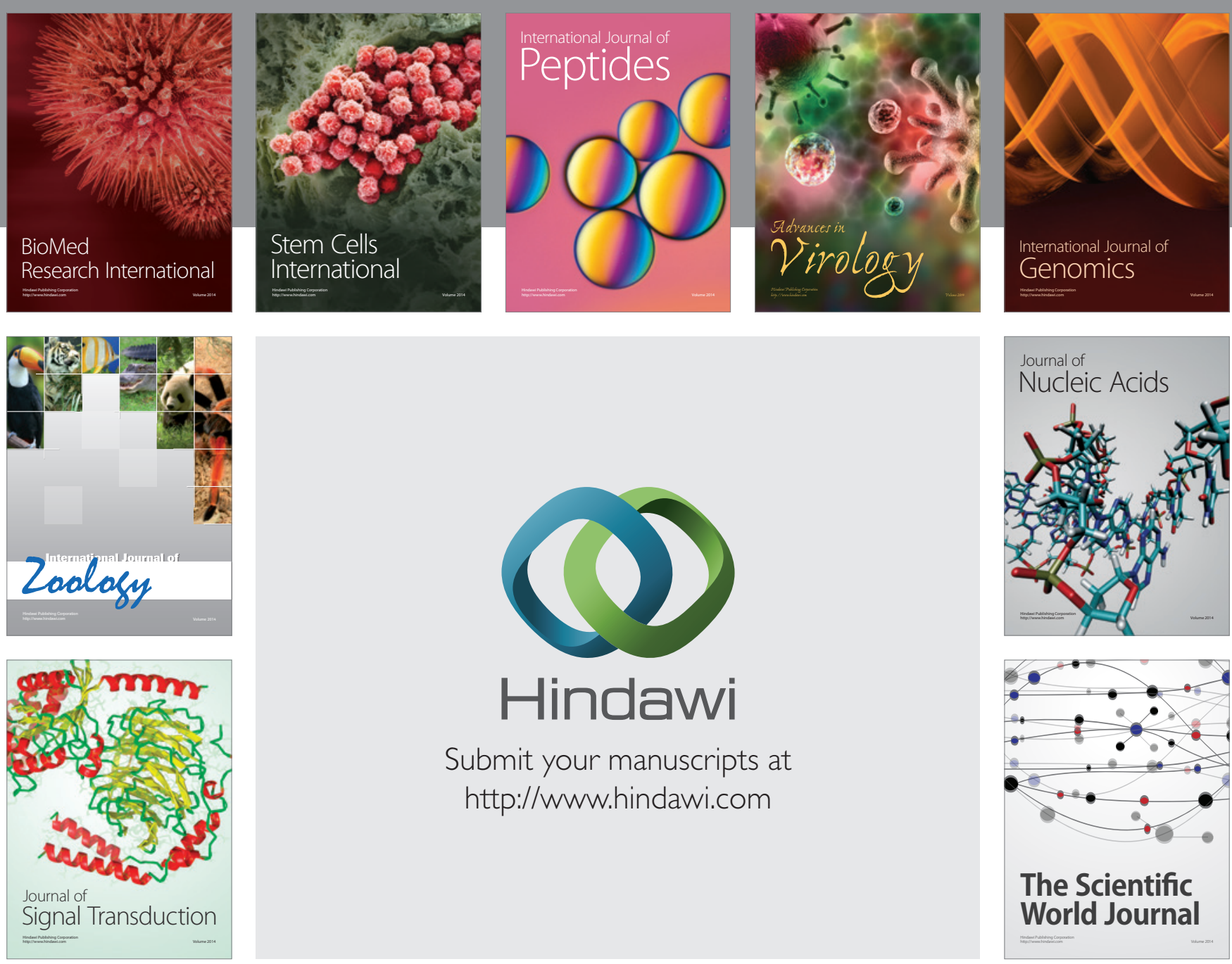

Submit your manuscripts at

http://www.hindawi.com
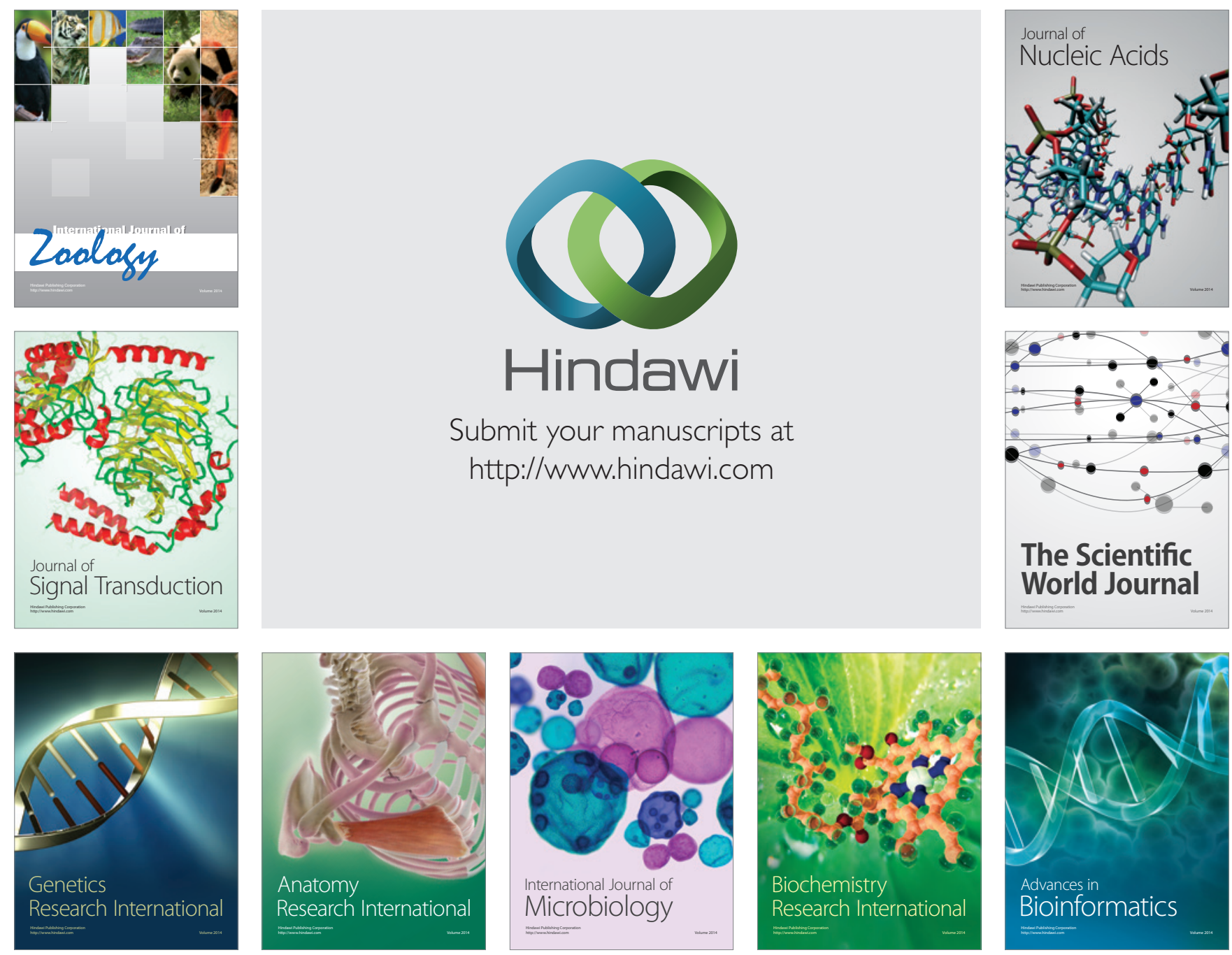

The Scientific World Journal
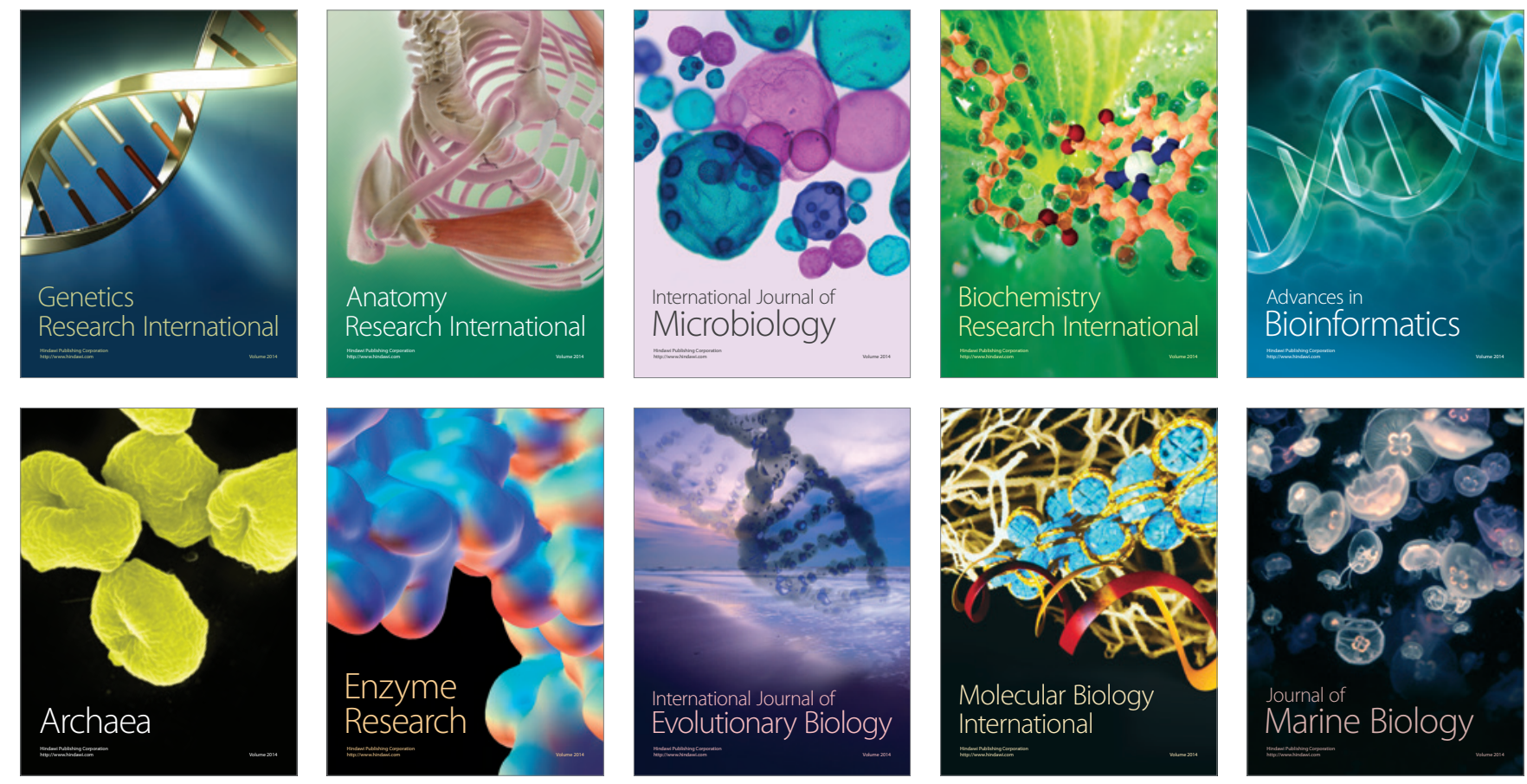